\title{
Sprawozdanie z konferencji „(Re)konstrukcje strojów ludowych a manifestowanie przynależności regionalnej", 11-12 października 2019 roku, Rzeszów
}

Organizatorami ogólnopolskiej konferencji naukowej „(Re)konstrukcje strojów ludowych a manifestowanie przynależności regionalnej” były instytucje: Sekcja Stroju Ludowego ZG Polskiego Towarzystwa Ludoznawczego, Muzeum Etnograficzne im. Franciszka Kotuli, Oddział Muzeum Okręgowego w Rzeszowie oraz Polskie Towarzystwo Ludoznawcze, Oddział w Lublinie. Zagadnienie to, we współczesnej, zglobalizowanej i nieustannie zmieniającej się rzeczywistości, staje się niezwykle interesujące dla osób zajmujących się etnologią i antropologią kulturową, jak również działających w obrębie edukacji i upowszechniania dziedzictwa kulturowego regionów. Mimo że strój ludowy zaczął stopniowo zanikać $\mathrm{w}$ pierwszej połowie XX wieku i był zastępowany tańszą odzieżą fabryczną, nigdy do końca nie uległ zapomnieniu i nie stracił na znaczeniu. W okresie powojennym nastąpiła transformacja i folkloryzacja tego elementu dziedzictwa kulturowego. Jak podkreślają organizatorki wydarzenia: „Strój ludowy, czyli tradycyjny ubiór mieszkańców wsi i miasteczek, w ostatnich kilkudziesięciu latach stał się ważnym elementem tożsamości lokalnej i regionalnej [...] - strój stał się ważnym elementem podtrzymującym tożsamość regionalną wielu wspólnot $\mathrm{z}$ terenu całego kraju". Zmiana funkcji tego elementu dziedzictwa kulturowego wymagała podjęcia odpowiednich działań, między innymi takich, jak: rekonstrukcja i odtwarzanie poszczególnych strojów regionalnych i lokalnych, współpraca międzyśrodowiskowa i międzyinstytucjonalna w tym zakresie, wykorzystanie zdobnictwa strojów ludowych w działalności projektantów mody, promocji regionów, działalności edukacyjnej i upowszechniającej dziedzictwo kulturowe regionów. Wokół tak sformułowanych zagadnień ogniskowały się wystąpienia prelegentów i dyskusje zgromadzonych uczestników. 
Muzeum Etnograficzne im. Franciszka Kotuli w Rzeszowie przywitało dwadzieścia sześć osób, które wygłosiły swe referaty w pięciu sesjach, oraz licznie przybyłych słuchaczy i słuchaczki. W pierwszej sesji wystąpiły badaczki zarówno z Polski, jak i z zagranicy. Sesję otworzyła Klara Brožovičová, przybliżając zagadnienie transmisji tradycji noszenia strojów ludowych na Morawach Południowych (Czechy). Z kolei Olena Kozakiewicz omówiła wyniki badań własnych dotyczących rekonstrukcji technik i zdobień kobiecych czepców ażurowych stanowiących element stroju tradycyjnego na Pokuciu. Temat współczesnej rekonstrukcji i transpozycji strojów ludowych podhalańskich przeanalizowała Stanisława Trebunia-Staszel, a w odniesieniu do powiatu wołomińskiego Elżbieta Piskorz-Branekova. Tę część konferencji zamykał referat Anny Drożdż, poświęcony zasobom fotograficznym archiwum Polskiego Atlasu Etnograficznego o tematyce ubioru ludności wiejskiej.

Drugą sesję otworzyła Joanna Miksztym, która omówiła proces rekonstrukcji strojów ludowych na przykładzie stroju bamberskiego i kościańskiego. To i kolejne wystąpienie, Pawła Całka („Przywrócenie kompletności stroju tradycyjnego z parafii Kołbiel, południowo-wschodnie Mazowsze”), przybliżały perspektywę praktyków. O kwestiach związanych z użytkowaniem odzieży tradycyjnej po II wojnie światowej na terenach tzw. Ziem Odzyskanych opowiedziały Anna Czachorowska („Rekonstrukcja czy konstrukcja - uwagi do historii powojennych badań nad strojem Warmiaków i Mazurów”) i Aleksandra Paprot-Wielopolska („Rekonstrukcje i kreacje strojów ludowych na Ziemiach Zachodnich i Północnych jako przejaw kształtujących się tożsamości lokalnych i regionalnych").

W sesji popołudniowej prezentowano przede wszystkim podsumowania eksploracji terenowych. Katarzyna Ignas mówiła o działaniach zmierzających do przygotowania modeli strojów folklorystycznych i estradowych zrekonstruowanych na podstawie kolekcji strojów ludowych Muzeum w Przeworsku. Tymoteusz Król analizował stosunek dzisiejszych użytkowniczek stroju wilamowskiego do poszczególnych jego elementów. Z wystąpienia Doroty Angutek słuchacze dowiedzieli się, jaka jest zależność pomiędzy ludowym strojem krajniackim a współczesnym strojem krajeńskim. Prelegentka oparła swój referat na wynikach badań terenowych i archiwalnych prowadzonych w latach 2017-2019. Na koniec Mariola Tymochowicz przybliżła kierunek przemian, jakie zaszły $\mathrm{w}$ zakresie strojów scenicznych na Lubelszczyźnie.

Kolejny dzień konferencji otwierała czwarta sesja, w której głos oddano osobom zajmującym się działalnością edukacyjną i upowszechniającą dziedzictwo kulturowe regionu oraz inspirującym się tradycyjnym zdobnictwem ludowym. W tej części spotkania Magdalena Fołta opowiedziała o zdobieniu tkanin techniką batiku, natomiast Aleksandra Pluta - o krajce, jako elemencie stroju. Justyna Majerska-Sznajder poruszyła problematykę współczesnego męskiego stroju wilamowskiego („»Bantuł, mantuł, ibercijer«, czyli o współczesnym, wilamowskim stroju męskim"), a zagadnienie zmiany funkcji piekielnicy - elementu kobiecego 
stroju rawickiego przybliżyła Alicja Gniazdowska. Na funkcji tożsamościowej stroju na pograniczu lachowsko-pogórzańskim skupił się Patryk Rutkowski.

Piąta, ostatnia sesja przebiegała pod znakiem kolejnych studiów przypadków. Grzegorz Ślesicki przedstawił przebieg działań dotyczących rekonstrukcji, zdobnictwa i współpracy w zakresie popularyzacji stroju ziemi zawkrzeńskiej, a Maciej Jastrzębski wygłosił referat „Opis stroju ludności Urzędowa i okolic na przełomie XIX i XX wieku - problemy współczesnego badacza strojów ludowych". Trzy ostatnie wystąpienia dotyczyły obszaru Górnego Śląska. Elżbieta Oficjalska podjęła temat: „Strój wspólnoty herrnhutów na przykładzie Gnadenfeld (Pawłowiczki) na Górnym Śląsku”, Ewa Cudzich omówiła procesy trwania, naśladownictwa i innowacji na przykładzie stroju górali Beskidu Śląskiego, natomiast Magdalena Toboła-Feliks pochyliła się nad zależnością między rekonstrukcją przeszłości a konstrukcją przyszłości w odniesieniu do stroju rozbarskiego. Sesję zamykało wystąpienie Joanny Dziadowiec-Greganić i Agnieszki Dudek, które było promocją publikacji Handmade in Wiśniowa. Wiśniowsko rócno robota. O najbardziej materialnym $z$ niematerialnych aspektów dziedzictwa kulturowego w pogranicznej gminie Wiśniowa (wydanej w 2019 roku przez Gminny Ośrodek Kultury i Sportu w Wiśniowej oraz Polskie Towarzystwo Ludoznawcze).

Konferencji w Rzeszowie towarzyszyły wydarzenia dodatkowe, nie tylko wzbogacające wiedzę uczestników, ale również umożliwiające zdobycie praktycznych umiejętności z zakresu zdobnictwa. Na zakończenie pierwszego dnia wszyscy zainteresowani mogli wziąć udział w warsztatach haftu rzeszowskiego (prowadzenie Bartłomiej Jankiewicz) oraz zdobienia tkanin batikiem (prowadzenie Magdalena Fołta). Drugi dzień obrad zakończyło zwiedzanie zmodernizowanej wystawy stałej zatytułowanej „Na co dzień i od święta”, prezentującej elementy strojów ludowych znajdujących się w zbiorach Muzeum Etnograficznego im. Franciszka Kotuli.

Referaty zaprezentowane podczas kolejnych sesji oraz prowadzone dyskusje pokazały, jak ważnym, wielowątkowym zagadnieniem jest strój ludowy zarówno z punktu widzenia ekspertów - naukowców i muzealników, jak również wytwórców, użytkowników czy popularyzatorów. 